\title{
Glutathione S-transferase Mu (GSTM1) null genotype in relation to gender, age and smoking status in a healthy Brazilian population
}

\author{
Roberta Losi-Guembarovski, Luciana Paula Grégio D’Arce and Ilce Mara de Syllos Cólus \\ Departamento de Biologia Geral, Centro de Ciências Biológicas, Universidade Estadual de Londrina, \\ Campus Universitário, 86.051-970 Londrina, PR, Brazil.
}

\begin{abstract}
The glutathione S-transferase mu (GSTM1) gene which acts during phase II of xenobiotic metabolism is polymorphic in the population, being absent in about $30-50 \%$ of individuals depending on the ethnic group from which they come. Epidemiological studies suggest that individuals who are homozygous null at the GSTM1 locus may have an increased risk of developing various types of neoplastic disease. We used the polymerase chain reaction (PCR) to estimate the frequency of GSTM1 in 176 healthy individuals from the north of Paraná (Brazilian state), the null genotype being detected in $48.86 \%$ of these individuals. The Student's t-test was used to evaluate the frequency of the glutathione S-transferase null genotype in relation to age, gender and smoking habit and no significant differences were found. In our sample there were 142 individuals of Caucasian origin, of which $47.88 \%$ had the null genotype. When applied to the Caucasian group only $(n=142)$ the Student's t-test again showed no significant differences between the frequency of the GSTM1 null genotype and age, gender and smoking habit.
\end{abstract}

Key words: glutathione S-transferase Mu (GSTM1), control individuals, Brazilian population, age, smoking habit.

Received: April 4, 2002; accepted: August 13, 2002.

\section{Introduction}

The differential distribution of variant polymorphic genes in different human populations around the world may influence the environmental diseases which they acquire (Au et al. 1999). The frequency of the GSTM1 null genotype in humans ranges from $30-50 \%$ depending on the ethnic origin of the individual (London et al. 1995). Epidemiological studies suggest that individuals who are homozygous null at the GSTM1 locus (i.e. lack both copies of the GSTM1 variant of the GST gene) may have an increased risk of developing various types of neoplastic disease, including cancer of the bladder, colon, skin, lung and stomach (Ford et al. 2000; Harada et al. 1987; Hayes and Pulford 1995; Johns and Houlston 2000; Raunio et al. 1995; Zhong et al. 1993a). Therefore, the knowledge of inheritance of these susceptible genes in different ethnic groups is very important for effective disease prevention, especially against cancer (Au et al. 1999).

Many of the first reports on genetic risk modification came from Japan, and, after several studies, genotypes associated with cancer risk have also been obtained for Caucasian and other population (Raunio et al. 1995). The frequency of the GSTM1 null genotype in healthy popula-

Send correspondence to Roberta Losi-Guembarovski. E-mail: aldalg@uol.com.br. tions ranges from $23-41 \%$ in African-Americans and Blacks, 33-69\% in Asiatics, 39-62\% in Europeans and $51-54 \%$ in Australians. The highest frequencies (64-100\%) have been reported in studies involving small numbers of subjects from parts of the South Pacific (Cotton et al. 1999). The variations in GSTM1 expression among control populations presents great difficulties for researchers in the selection of suitable control groups to be used for determining the association between GST genotype and disease susceptibility (Hayes and Pulford 1995).

The ethnic origin of the Brazilian population is highly heterogeneous, the population being composed of Indigenous peoples and immigrants from Europe, Africa and Asia (Arruda et al. 1998). Studies on healthy Brazilians have shown a frequency of the GSTM1 null genotype of 33\% (D'Arce and Cólus, 2000) and 41.2\% (Cabral et al., 1999).

Currently there has been great interest in studies of genes which code for enzymes able to metabolize xenobiotics, although studies involving Brazilian populations are rare. The aim of our study was to estimate the frequency of the GSTM1 gene in a group of healthy Brazilians from the state of Paraná and characterize the sample according to the presence or absence of this gene regarding gender, age and smoking habits. 


\section{Materials and Methods}

\section{Population studied}

We used blood samples from 176 people born in the north of the southern Brazilian state of Paraná, the sample consisting of individuals whose ancestors were Caucasians $(\mathrm{n}=142)$, Africans $(\mathrm{n}=13)$, Asians $(\mathrm{n}=10)$ and Brazilian Indians $(n=5)$. It was not possible to determine the ethnic group which belong some individuals $(\mathrm{n}=6)$, due to doubtful informations in the questionnaire. Those individuals, however, have been analyzed in the total sample. After the subjects' had given their consent, personal information regarding life style, age, marital status, ethnic group, occupational history, smoking habits, family history of cancer and others factors was obtained according to the procedures of Carrano and Natarajan (1988).

\section{Genotype analyses}

DNA was isolated from the peripheral white blood cells of all the individuals sampled using the technique described by Miller et al. (1988) and the GSTM1 genotype determined by a modification of the polymerase chain reaction (PCR) procedure described by Topinka et al. (1997). The oligonucleotide primers (P1, P2, P3) used for the PCR were 5'-CGC CAT CTT GTG CTA CAT TGC CCG-3' (P1), 5'-ATC TTC TCC TCT TCT GTC TC-3' (P2) and 5'TTC TGG ATT GTA GCA GAT CA-3' (P3). The three primers were used together in the reaction and formed two couples as follows: pair P1 and P2 (which anneal with homologous sequences of genes GSTM1 and GSTM-4) yielded one $157 \mathrm{bp}$ fragment used as internal control for the reaction and pair P1 and $\mathrm{P} 3$ (specific for the polymorphic gene GSTM1) produced a fragment of $230 \mathrm{bp}$ (Figure 1). The PCR was carried out in a volume of $25 \mu \mathrm{L}$ containing $10 \mathrm{mM} \mathrm{pH} 8.3$ Tris-HCL, $50 \mathrm{mM} \mathrm{KCL}, 1.0 \mathrm{mM} \mathrm{MgCL} 2$, $5 \%$ DMSO, $2.5 \mathrm{mM}$ of each dNTP, 50-200 ng of genomic DNA, 1.5 units of Taq DNA polymerase (Life Technologies, Bethesda, MD, USA), $200 \mathrm{mM}$ of primer 1 and 100 $\mathrm{mM}$ each of primers 2 and 3. Incubation was for 35 cycles of $94{ }^{\circ} \mathrm{C}$ at $1 \mathrm{~min}, 52^{\circ} \mathrm{C}$ at $1 \mathrm{~min}$ and $72^{\circ} \mathrm{C}$ at $1 \mathrm{~min}$. The reaction was amplified using a thermal cycler PTC-100 (M.R. Research) and the PCR products separated by electrophoresis in $1.8 \%$ agarose gel and visualized by staining with ethidium bromide $(10 \mathrm{mg} / \mathrm{mL})$.
M C 12334566789101112131415161718

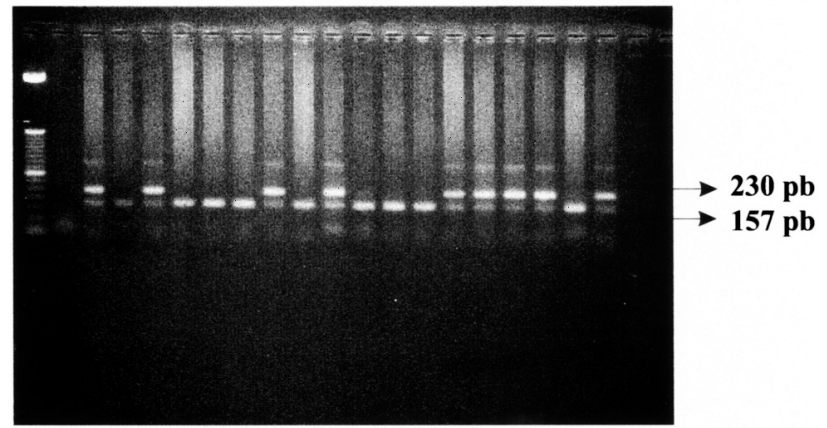

Figure 1 - GSTM1 gene PCR products resolved by agarose gel electrophoresis. $\mathrm{M}$ is a $50 \mathrm{bp}$ DNA Ladder and $\mathrm{C}$ is the Control. A $157 \mathrm{pb}$ DNA fragment can be seen in all the PCR reactions and a 230 bp DNA fragment is only present in samples containing the GSTM1 gene.

\section{Statistical analyses}

The Student's t-test was used to test the relationship between the GSTM1 null genotype and the smoking habits, age and gender of individuals from the total sample $(n=176)$ and the Caucasian subsample $(n=142)$. Statistical analysis was carried out using the Statgraphics (1989 version) software package (Statistical Graphics Corp.).

\section{Results}

The frequency of the GSTM1 null genotype for the total sample ( $\mathrm{n}=176)$ was $48.86 \%$ and $47.88 \%$ for the Caucasian subsample $(n=142)$. No statistical differences were detected in regard to age, gender and smoking habits in either the total sample (Table I) or the Caucasian subsample (Table II).

\section{Discussion}

Many genetic polymorphisms in metabolic enzymes are important risk factors in cancer, as has been shown in the large number of case-control studies which have been undertaken and the relative risk estimates have shown large variations between such populations studies (Knudsen et al. 2001). The GSTM1 gene acts during phase II of xenobiotics metabolism and its correspondent enzyme plays an important role in detoxifying chemical compounds, including polyaromatic hydrocarbons, such as those found in cigarettes, foods, pollutants, agrochemicals, chemotherapeutic drugs and oxidative stress products (Conde et al. 1999; Hirvonen 1995; London et al. 1995; Zhong et al. 1993b).

Table I - Number of individuals and frequency (\%) of the GSTM1 null genotype in the total sample according to age, gender and smoking habits.

\begin{tabular}{|c|c|c|c|c|c|c|c|c|}
\hline & \multicolumn{3}{|c|}{ Age } & \multicolumn{2}{|c|}{ Gender } & \multicolumn{2}{|c|}{ Smoking habits } & \multirow[t]{2}{*}{ Tota } \\
\hline & $17-30$ & $31-50$ & $>50$ & Male & Female & Non-smokers & Smokers & \\
\hline Number of individuals & 87 & 72 & 17 & 85 & 91 & 151 & 25 & 176 \\
\hline GSTM1 null frequency $(\%)$ & 43.67 & 51.38 & 58.82 & 47.05 & 50.54 & 49 & 48 & 48.86 \\
\hline
\end{tabular}


Table II - Number of individuals and frequency (\%) of the GSTM1 null genotype in the Caucasian subsample according to age, gender and smoking habits.

\begin{tabular}{|c|c|c|c|c|c|c|c|c|}
\hline & \multicolumn{3}{|c|}{ Age } & \multicolumn{2}{|c|}{ Gender } & \multicolumn{2}{|c|}{ Smoking habits } & \multirow[t]{2}{*}{ Total } \\
\hline & $17-30$ & $31-50$ & $>50$ & Male & Female & Non-smokers & Smokers & \\
\hline Number of individuals & 79 & 50 & 13 & 61 & 81 & 124 & 18 & 142 \\
\hline GSTM1 null frequency (\%) & 41.77 & 54 & 69.23 & 49.18 & 48.14 & 50 & 38.88 & 47.88 \\
\hline
\end{tabular}

Brazil is a large and highly heterogeneous country in regard to population, and differences in genic frequencies for control populations are easily found in different regions. The frequency of the GSTM1 null genotype (48.86\%) which we found in the 176 healthy individuals of our sample drawn from the South of the country is similar to the frequency obtained by Buim (1999) and Cabral et al. (1999) in studies with healthy individuals from the Southern and Northern regions of Brazil as well as that obtained with other control populations (Zhong et al. 1993b). However, a lower GSTM1 null genotype frequency $(36.9 \%)$ was reported by Arruda et al. (1998) in a Brazilian control population from the North, Northeast and Southeast.

We also analyzed the frequency of the GSTM1 null genotype according to gender, age and smoking habits. The GSTM1 gene was absent in $47.05 \%$ of the men and $50.54 \%$ of the women, but this difference was not statistically significant, this being similar to the results obtained by Alexandrie et al. (1994) and Kihara et al. (1994). The frequencies we obtained for the three age groups were $43.67 \%$ for the $17-30$ group, $51.38 \%$ for the $31-50$ group and $58.82 \%$ for the $>50$ group. Rossit et al. (1999) in a GSTM1 gene polymorphism study with Brazilians from $15-60$ year-old, obtained a frequency of $47.7 \%$ for the null genotype. In our study, the null genotype seems to increase with age, although this was not statistically significant. Additional studies are necessary to confirm this tendency because we had no individuals younger than 17 years old in our study.

Genetic polymorphisms of metabolic enzymes have been demonstrated as an important risk factor in the development of cancer when combined with exposures of tobacco smoke (Knudsen et al. 2001). According to Kihara et al. (1994), the development of lung cancer depends on the smoking habit and the null GSTM1 genotype is one of the genetic factors involved in the individual response to smoke exposure and tumor development. Thus, the elaboration of studies to determine the frequency of this gene in control populations is of great importance to cancer prevention.

Different ethnic groups show differences regarding the presence and the absence of the GSTM1 gene which may influence the efficiency and interpretation of epidemiological studies, and because of this there is a great need to study the frequency of this gene in different ethnic groups (Lin et al. 1994).
The ethnic distribution of the GSTM1 null genotype has been studied mainly in Caucasian populations and, for this ethnic group, the frequency of the null genotype $(47.88 \%)$ obtained in our study is similar to that described in the literature for healthy white populations of different nationalities (Gawronska-Szklarz et al. 1999; Lin et al. 1994; Stücker et al. 1999). Nevertheless, Arruda et al. (1998) and Gattás and Soares-Vieira (2000) have reported the absence of the GSTM1 gene in $55 \%$ and $60.2 \%$ of Caucasians in populations from Southeast Brazil.

In our study, no statistical differences were found regarding the absence of the GSTM1 gene according to gender, age and smoking habit among the Caucasians, corroborating the results described by London et al. (1995) who found no statistical differences for the null genotype in respect of any of these parameters for a Caucasian population from the USA.

The present study regarding the determination of the GSTM1 gene frequency in a Brazilian control population is an important contribution for future bio-monitoring studies which aim to assess risk from exposure to xenobiotics, especially because there is little data in the literature regarding Latin America populations in general and Brazilian populations in particular. Data obtained from different regions of Brazil may prove useful in explaining the different immigration patterns that occurred in the various regions of Brazil and for national epidemiological studies.

\section{Acknowledgments}

We would like to thank Liliane Moreira Nunes for revising the English and Dário P. Tormena for his technical assistance. Our thanks also go to LabImagem, Hemocentro and Hospital de Clínicas da Universidade Estadual de Londrina for blood collection. This work was financed by Coordenação de Aperfeiçoamento de Pessoal de Nível Superior (CAPES) and Universidade Estadual de Londrina (PR), Brazil.

\section{References}

Alexandrie A, Sunderberg MI, Seidegard J, Tornling G and Rannug A (1994) Genetic susceptibility to lung cancer with special emphasis on CYP1A1 and GSTM1: a study on host factors in relation to age at onset, gender and histological cancer types. Carcinogenesis 15:1785-1790.

Arruda CVR, Grinolli ME, Gonçalves MS, Soares MC, Menezes R, Saad STO and Costa, FF (1998) Prevalence of 
homozygosity for the deleted alleles of glutathione S-transferase mu (GSTM1) and theta (GSTT1) among distinct ethnic groups from Brazil: relevance to environmental carcinogenesis? Clin Genet 54:210-214.

$\mathrm{Au}$ WW, Torres CHS, Salazar NC and Salama AS (1999) Inheritance of polymorphic metabolizing genes and environmental disease and quality of life. Mutat Res 428:131-140.

Buim ME (1999) Fatores genéticos na resposta à exposição ocupacional de agricultores Paranaenses a agroquímicos. Master Dissertation, Universidade Estadual de Londrina, Londrina.

Cabral IR, Rossit AR and Hamel AR (1999) Polimorfismos em genes de biometabolismo e prevalência do alelo CYP2E1*c2 em deficientes de G6PD assintomáticos: análises em uma população paraense. Genet Molec Biol 22 (suppl): 236-237. IV Congresso da Sociedade Brasileira de Mutagênese, Carcinogênese e Teratogênese Ambiental, Águas de Lindóia, Brazil.

Carrano AV and Natarajan AT (1988) Considerations for population monitoring using cytogenetic techniques. Mutat Res 204:381.

Conde AR, Martins G, Saraiva C, Rueff J and Monteiro C (1999) Association of P53 and glutathione S-transferase null genotype in gastric cancer in Portuguese population. Clin Mol Pathol 52:131-134.

Cotton SC, Sharp LJ and Brockton N (1999) Glutathione S transferase polymorphisms and colorectal cancer. Am J Epidemiol 1-18.

D'Arce LPG and Cólus IMS (2000) Cytogenetic and molecular biomonitoring agricultural workers exposed to pesticides in Brazil. Teratog Carcinogen and Mutagen 20:161-170.

Ford JG, Li Y, O'Sullivan MM, Demopoulos R, Garte S, Taioli E and Rauf PWB (2000) Glutathione S-transferase M1 polymorphism and lung cancer risk in African-Americans. Carcinogenesis 21:1971-1975.

Gattás GJF and Soares-Vieira JA (2000) Cytochrome P450-2E1 and Glutathione S-transferase mu polymorphisms among Caucasians and mulattoes from Brazil. Occup Med 50:508-511.

Gawronska-Szklarz B, Wójcicki M, Kuprianowicz A, Kedzierska K, Kedzierski M, Górnik W and Pawlik A (1999) CYP2D6 and GSTM1 genotypes in a Polish population. Eur J Clin Pharmacol 55:389-392.

Harada S, Abei M, Tanaka N, Agarwal DP and Goedde HW (1987) Liver glutathione S-transferase polymorphism in Japanese and its pharmacogenetic importance. Hum Genet 75:322-325.

Hayes JD and Pulford DJ (1995) The Glutathione S-transferase supergene family: regulation of GST and the contribution of the isoenzymes to cancer chemoprotection and drug resistance. Crit Rev Biochem Mol Biol 30:445-600.
Hirvonen A (1995) Genetic factors in individual responses to environmental exposures. J Occup Environ Med 37:37-41.

Johns LE and Houlston RS (2000) Glutathione S-transferase $\mu \mathrm{L}$ (GSTM1) status and bladder cancer risk: a meta-analysis. Mutagenesis 15:399-404.

Kihara M, Kihara M and Noda K (1994) Lung cancer risk of GSTM1 null genotype in dependent on the extent of tabaco smoke exposure. Carcinogenesis 15:415-418.

Knudsen LE, Loft SH and Autrup H (2001) Risk assessment: the importance of genetic polymorphisms in man. Mutat Res 482: 83-88.

Lin HJ, Han CY, Bernstein DA, Hsiao W, Lin BK and Hardy S (1994) Ethinic distribution of the glutathione transferase $\mathrm{Mu}$ 1-1 (GSTM1) null genotype in 1473 individuals and application to bladder cancer susceptibility. Carcinogenesis 15:1077-1081.

London SJ, Daly AK, Cooper J, Navidi WC, Carpenter CL and Idle JR (1995) Polymorphysm of glutathione S-transferase M1 and lung cancer risk among African-American and Caucasians in Los Angeles County, California. J Natl Cancer Inst 87:1246-1253.

Miller AS, Dykes DD and Polesky HF (1988) A simple salting out procedure for extraction DNA from human nucleated cells. Nucleic Acid Res 16:1215.

Raunio H, Pursiainen KH, Anttila S, Hietanen E, Hirvonen A and Pelkonen O (1995) Diagnosis of polymorphisms in carcinogen-activating and inactivating enzymes and cancer susceptibility- a review. Gene 159:113-121.

Rossit ARB, Cabral IR, Hamel AR and Conforti-Froes NDT (1999) Estariam as freqüências de genes do biometabolismo sujeitas à pressão seletiva durante o desenvolvimento humano? Genet Molec Biol 22 (suppl): 218. IV Congresso da Sociedade Brasileira de Mutagênese, Carcinogênese e Teratogênese Ambiental, Águas de Lindóia, Brazil.

Stücker I, Waziers I, Cenée S, Bignon J, Depierre A, Milleron B, Beaune P and Hémon D (1999) GSTM1, smoking and lung cancer: a case control study. Int J Epidemiol 28:829-835.

Topinka J, Binkova B, Mrackkvá G, Stávková Z, Peterka V, Benes I, Dejmek J, Lenícek J, Pilcík J and Srán RJ (1997) Influence of GSTM1 and NAT2 genotypes on placental DNA adducts in a environmentally exposed population. Environ Mol Mutagen 30:184-195.

Zhong S, Wyllie AH, Barnes D, Wolf CR and Spurr NK (1993a) Relationship between the GSTM1 genetic polymorphism and susceptibility to bladder, breast and colon cancer. Carcinogenesis 14:1821-1824.

Zhong S, Spurr NK, Hayes JD and Wolf CR (1993b) Deduced amino acid sequence, gene structure and chromosomal location of a novel human class $\mathrm{Mu}$ glutatione S-transferase, GSTM4. Biochem J 291:41-50. 